\title{
ELECTRICAL RESISTIVITY SOUNDINGS OF GLACIER BEDS: A TEST STUDY ON GRUBENGLETSCHER, WALLIS, SWISS ALPS
}

\author{
By Wilfried Haeberli \\ (Versuchsanstalt für Wasserbau, Hydrologie und Glaziologie, E.T.H. Zürich, CH-8093 Zürich, Switzerland) \\ and Werner Fisch
}

(Im Wiesengrund 13, CH-8907 Wettswil, Zürich, Switzerland)

\begin{abstract}
Electrical resistivity sounding, using electrodes which are lowered directly to the ice-rock interface in bore holes, is proposed as a technique for studying the exact position of glacier beds, as well as their lithological characteristics. A test study is described on Grubengletscher, a partially cold Alpine glacier in Switzerland. Results of soundings along a $400 \mathrm{~m}$ long profile indicate that previous depth determinations, based on radio echo-soundings, were in general accurate to within less than $5 \%$ of the actual ice thickness. The results also show that the glacier rests on nonconsolidated sediments of considerable thickness. The proposed method could add substantial information about glacier sliding and glacier erosion, if applied alongside conventional deep drilling projects.
\end{abstract}

RÉsumé. Sondages de résistivité electrique dans le lit glaciaire: une mesure test a glacier de Gruben, Valais, Alpes suisses. Des sondages de résistivité électrique à l'aide d'électrodes installées dans des forages directement à l'interface glace-roche, sont proposés comme technique pour déterminer la position exacte du lit glaciaire ainsi que ses caractéristiques lithologiques. On décrit une mesure test réalisée au glacier de Gruben, glacier partiellement froid des Alpes suisses. Les résultats des mesures faites sur un profil de $400 \mathrm{~m}$ de long montrent que les épaisseurs de glace estimés au paravant par radio-echo

\section{INTRODUCTION}

The beds of existing glaciers are characterized by a wide variety of morphological and lithological conditions. These beds may be rough or smooth depending on the scale considered, and they may consist of rock or unconsolidated sediments. Sediments at glacier beds may or may not be frozen, and they may or may not contain ground-water. To know what conditions exist at the glacier bed in a specific case is important for several reasons.

Practical applications in connection with the planning and operation of Alpine hydroelectric power stations, such as the installation of subglacial water intakes or rock galleries for water adduction, may require the exact position and the lithological characteristics of glacier beds (e.g. Bezinge and others, 1973; Vivian and Zumstein, 1973; Wold and Østrem, 1979). From a scientific point of view, knowledge about glacier bed characteristics is essentially relevant to studies done on glacier sliding, (Lliboutry, 1979; Weertman, 1979; Iken, 1981; Iken and others, 1983) and to those which deal with processes of glacier erosion (Boulton, 1979; Collins, 1979; Röthlisberger and Iken, 1981).

Commercial projects mainly utilize core drillings, either from the glacier surface downwards or from already existing rock galleries upwards, to probe the glacier bed. Scientific studies have to try less expensive methods, such as hot-water drilling (e.g. Iken and others, 1977), geophysical soundings (Süsstrunk, 1951; Röthl isberger, 1967; Robin, 1975) observations with bore-hole cameras (Engelhardt and others, 1978), or observations in ice tunnels (Boulton, 1979). All these methods furnish information of limited accuracy or point information only. This paper proposes a method by which it is hoped to be able partially to fill this gap: electrical resistivity soundings of glacier beds. sondage ne déviaient en général que de $5 \%$ de la valeur exacte. D'autre part, on a trouvé que la langue du glacier se trouve sur des sédiments non consolidés d'épaisseur considérable. En appliquant la méthode proposée lors de campagne de forage conventionelle, on pourrait obtenir d'importantes informations supplémentaires sur le glissement et l'érosion des glaciers.

Zusammenfassung. Elektrische Widerstandssondierungen am Gletscherbett: eine Testmessung am Grubengletscher, Wallis, Schweizer Alpen. Elektrische Widerstandssondierungen mit Elektroden, die in Bohrlöchern direkt an der Eisuntergrenze installiert werden, werden für die Untersuchung der genauen Lage und der lithologischen Charakteristik von Gletscherbetten vorgeschlagen. Eine Testmessung am Grubengletscher, einem teilweise kalten Gletscher der Schweizer Alpen, wird beschrieben. Ergebnisse einer Sondierung auf einem $400 \mathrm{~m}$ langen Profil zeigen, dass mit Radioecholot zuvor bestimmte Eistiefen im allgemeinen um weniger als $5 \%$ von der effektiven Eistiefe abweichen. Die Gletscherzunge liegt auf unverfestigten Sedimenten von beträchtlicher Mächtigkeit. Die vorgeschlagene Methode könnte im Rahmen von konventionellen Tiefbohrprojekten wichtige Information über Gletschergleiten und Gletschererosion liefern.

\section{PRINCIPLES OF THE METHOD}

The method is a combination of two well-known techniques: (thermal) drilling in ice and electrical resistivity soundings of sub-surface materials. Combining the two techniques helps to overcome the problems and limitations of interpreting results which occur when the techniques are applied separately. Standard resistivity techniques are applied directly at the glacier bed by lowering the electrodes down drill holes to the ice-rock interface. Such electrical measurements can help to define the exact position of the glacier bed, and, moreover, they provide information about lithological changes in a horizontal direction (between the bore holes) as well as in a vertical direction, down into the subglacial material.

Thermal drilling from the ice surface to the glacier bed often encounters the problem that increased amounts of rock particles included in the basal layer of glaciers gradually lower the drilling speed. Hotwater jets may finally wash out these inclusions and even penetrate into glacier bed sediments if they are fine-grained, whereas electrothermal drills will, in many cases, not completely reach the glacier bed. (Hot-water drilling has in this respect an advantage over electrothermal drilling.) In either case it is difficult to determine from observed drilling rates the exact position of the glacier bed. A simple electrical measurement, however, indicates whether and where a drill has reached the glacier bed. The array of the electrical measurement is shown in Figure 1a. The measurement is based on the fact that the specific electrical resistivity of temperate or nearly temperate glacier ice is usually much higher $\left(\rho_{j}>10^{7} \Omega \mathrm{m}\right)$ than that of the underlying rock material ( $\left.\rho_{r} \ll 10^{6} \Omega \mathrm{m}\right)$. A fixed electrode (FE) is grounded outside the glacier margin, usually in a pond or another water body to improve surface contact. $A$ second electrode, the bore-hole electrode (BE), is 

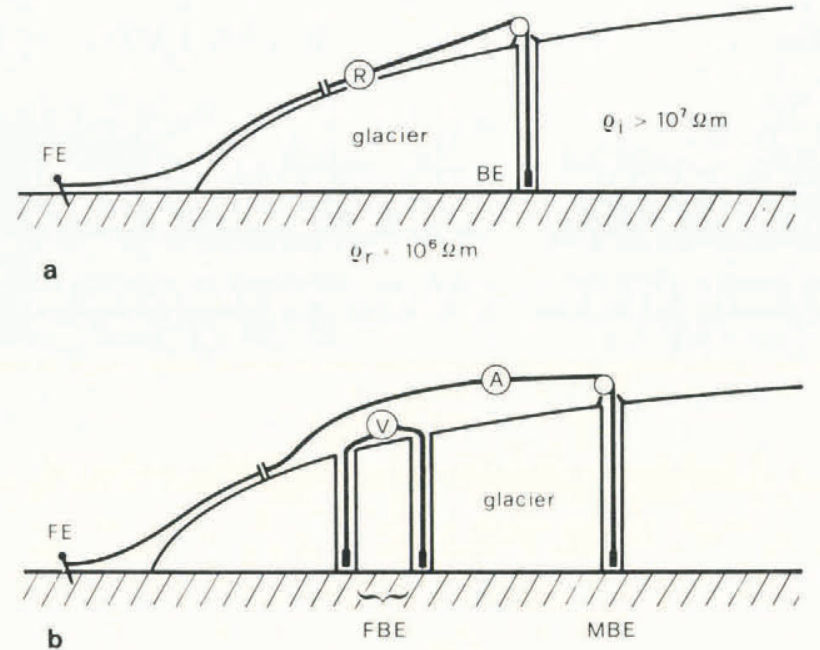

Fig. 1. Electrode arrays used for the determination of the exact position of the glacier bed (a) and for resistivity soundings of glacier beds (b). $F E=$ fixed electrode outside the glacier margins, $B E=$ bore-hole electrode for determination of glacier-bed position, $F B E=$ "fixed" bore-hole electrodes for resistivity soundings of glacier beds (corresponding to "potential elecirodes $M N^{\prime \prime}$ in traditional surface soundings), $M B E=$ "moving" bore-hole electrode for resistivity soundings of glacier beds, $R=$ Resistivity meter, $V=$ voltmeter,$A=$ Ammeter. years ago. Its steep front is presently overriding a tube which was installed in the perennially frozen silts and sands at the glacier margin in order to regulate the level of the lake.

The position of the profile is shown in Figures 2 and 3 . Bore holes were drilled with a hot water jet as described by Iken and others (1977). Observed ice

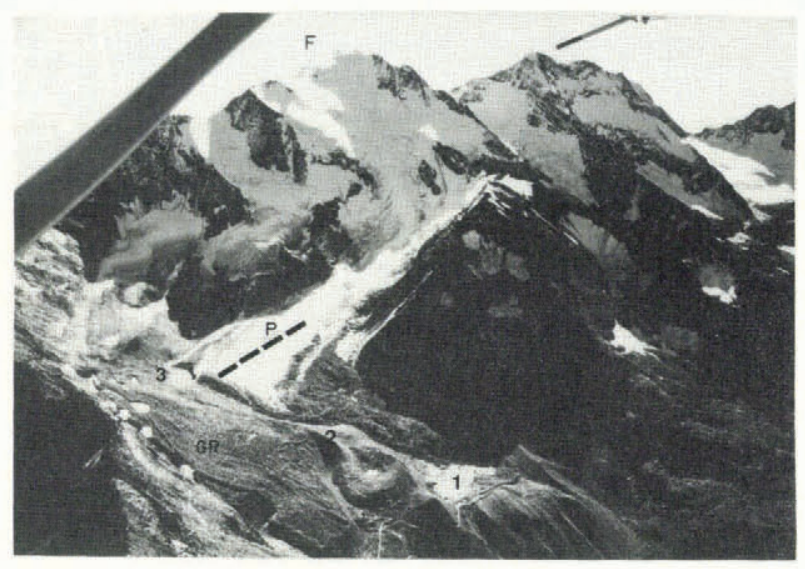

Fig. 2. Fletschhom (F) and Grubengletscher with electrical glacier-bed profile $P .1-4=$ lakes 1 to 4, GR = Gruben rock glacier, where permafrost is about $100 \mathrm{~m}$ thick. Aerial photograph taken by J. Alean, August 1982. lowered with the drill into the bore hole (the drill point itself may be used as an electrode). As long as the bore hole does not reach the glacier bed, the glacier will act as an almost perfect insulator. However, as soon as the bore-hole electrode reaches the ice-rock interface, the circuit is "completed", because much more current flows from BE to FE. This important moment can be detected easily at the glacier surface with a resistivity meter.

The drill holes reaching down to the glacier bed now permit the installation of electrodes directly at the glacier bed and make it possible to carry out resistivity soundings of the subglacial rock material. In this way, the problems of surface soundings on top of a highly insulating ice body (cf. Röthlisberger, 1967) are eliminated. Because of the high resistivity difference between the studied glacier bed material and the overlying glacier ice, the subglacial lithosphere can be considered as an electrical half-space. Operation and analysis of glacier bed resistivity soundings are therefore analogous to those from standard resistivity soundings using electrodes installed at air-rock interfaces. A schematic representation of the measuring array is given in Figure 1b. Additional information about the sounding technique itself is readily available from textbooks (e.g. Dohr, 1974). Typical values of specific resistivity for Alpine rock materials, such as crystalline rock, frozen ice-rich sediments and unfrozen sediments, with or without ground-water, have been compiled by Fisch and others ([1978]).

\section{The Grubengletscher experiment}

An electrical profile was measured at Grubengletscher in the summer of 1982. Grubengletscher is a partially cold glacier of the Wallis Alps, Switzerland (Haeberli, [1976]); it is frozen to its bed at the margins. This glacier has been, and still is, a point of intensive study because of two lake outbursts in 1968 and 1970 which both caused considerable damage to the nearby village of Saas Balen (Röthlisberger, 1979). After a period of glacier retreat, the glacier started to advance slowly a few thickness along the profile was between $25 \mathrm{~m}$ and $85 \mathrm{~m}$, values already obtained from radio echo-soundings carried out in the previous year. Bore-hole water froze within about one day, except when the level of this water was more than about 20-30 m below the surface - presumably in the transition zone between cold surface ice and deeper temperate ice. Electrical equipment was the Gga 30 of the Bodenseewerke Ueberlingen, West Germany (cf. King, 1982).

Figure 4 shows a comparison between ice thickness estimated from the radar map finished earlier (cf. Fig. 3) and ice thickness determined by drilling with bore-hole electrodes. If drilling with bore-hole electrodes is considered to be an almost perfectly precise method of ice thickness determination, then the accuracy of radio echo-soundings can be checked. This test, of course, does not apply to single radar measurements, but to the final result of threedimensional analysis, and interpretation of a large number of radio echo-soundings. Point measurements obtained by drilling with bore-hole electrodes therefore provide an evaluation of the accuracy of glacier bed maps compiled from radio echo-soundings. For the case under study, the U.S. Geological Survey Monopulse Ice Radar was used with $20 \mathrm{~m}$ antennae (c. 2.5 $\mathrm{MHz}$ ) and the velocity of electromagnetic wave propagation in ice was assumed to be $168 \mathrm{~m} / \mu \mathrm{s}$ (cf. Haeberli and others, 1982). The average difference between the depth determinations using radar and those from hot-water drillings with bore-hole electodes in 15 bore holes was $1.9 \%$ of the measured ice thickness. Extremes were $-3.4 \%$ and $+10.6 \%$, and the mean absolute value of the difference was $3.6 \%$. This confirms that depths measured by radar are usually within $\pm 5 \%$ of the actual ice thickness, but that less accurate values, with errors around $10 \%$ or more can also occur; in the latter cases, the radar method always underestimates the actual depth.

Figure 5 shows the resistivity curve measured at the glacier bed. Interpretation of the curve is based on a comparison with resistivity values measured in the region of the "Kintole" (Mischabel group, cf. Fisch and others, [1978]), where bedrock resistivity is 6000 to $12000 \Omega \mathrm{m}$ (gneiss of the Bernhard nappe), 

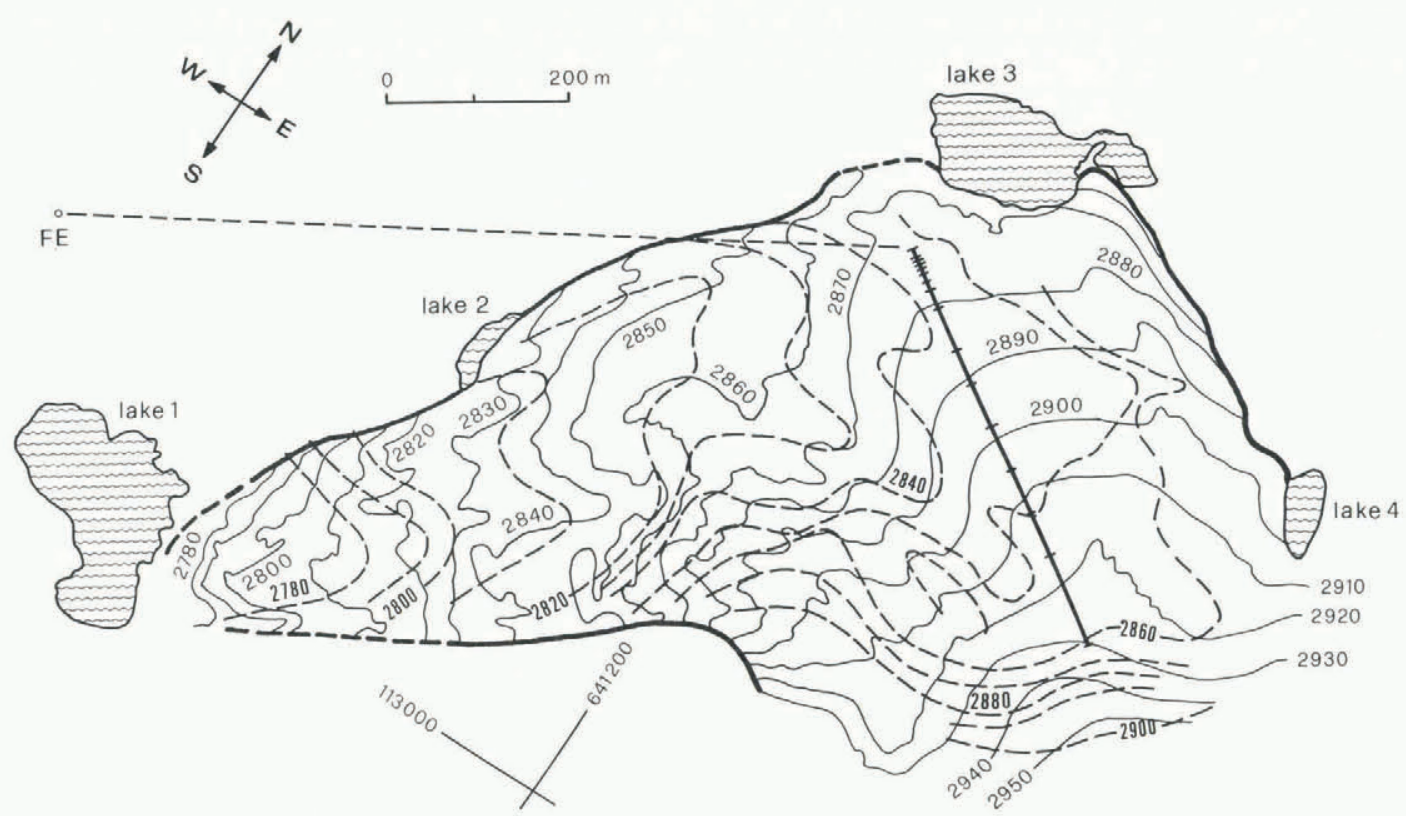

- glacier margin

glacier surface contour $(10 \mathrm{~m}$ intervals $)$

- glacier bed contour $\quad(10 \mathrm{~m}$ intervals

geoelectrical glacierbed profile, FE = fixed electrode

Fig. 3. Tongue of Grubengletscher with the electrical glacier-bed profile. Surface topography is from 1979, glacier-bed topography is from radio echosoundings carried out in 1981.

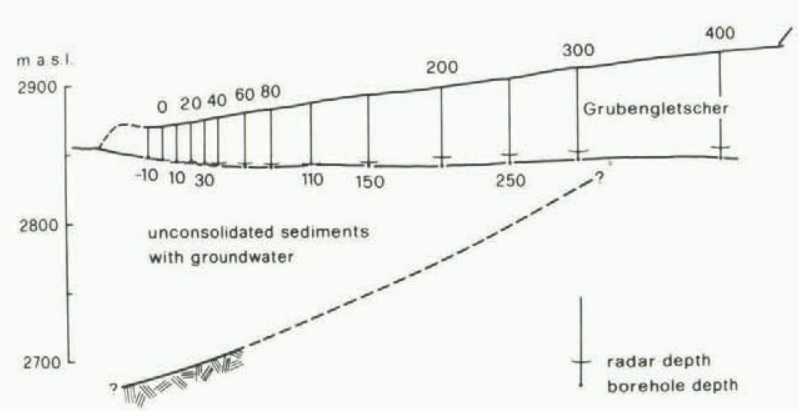

Fig. 4. Comparison of glacier-bed positions determined by radio echo-sounding and hot-water drilling with bore-hole electrodes respectively, and interpretation of measured electrical glacier-bed profile. Numbers on bore holes ( -10 to 400) indicate distances from an arbitrary zero in metres.

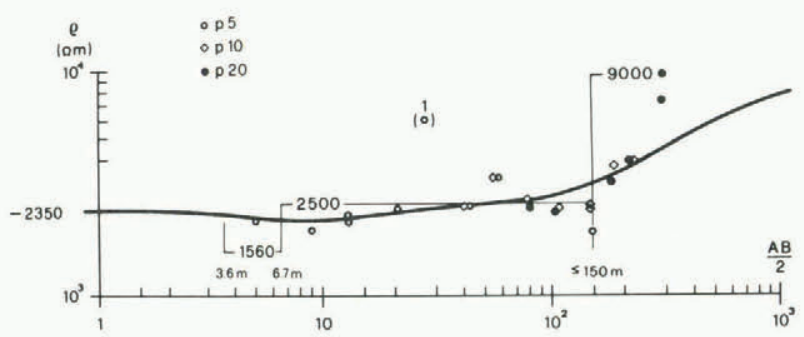

Fig. 5. Resistivity curve measured at the glacier bed. $A B$ corresponds to 0.75 times the distance between the $F E$ and the MBE electrode respectively (Wenner configuration). p5, p10, p20 indicate the centres of the FBE electrodes used for various $A B-d i s t a n c e s$ (cf Fig. 4). $\rho=$ apparent resistivity. resistivity of unfrozen, unconsolidated sediments 3000 to $4000 \Omega \mathrm{m}$ and that of frozen sediments rich in ice more than about $10000 \Omega \mathrm{m}$. The steep rise of the measured curve between $A B / 2=10^{2}$ and $10^{3}$ could theoretically represent frozen material. Morphological considerations and results from earlier bore-hole temperature observations (Haeberli, [1976]), however, suggest a steeply inclined bedrock surface here; this occurrence causes an unrealistically steep rise in the resistivity curve. Bedrock depth below bore hole 10 , which was the centre $(M / N)$ of the wider electrode spacings, is estimated at $150 \mathrm{~m}$ below the glacier bed, but because of the uncertainty of depth determinations using electrical resistivity soundings, 100 or $120 \mathrm{~m}$ could also be realistic. It remains beyond doubt, however, that a considerable thickness of subglacial sediments occurs underneath the tongue of Grubengletscher. The sediments, with their resistivity values of 1500 to $2500 \Omega \mathrm{m}$, are most likely to consist of unfrozen silts and sands containing ground-water; such sediments have been observed earlier when a core was drilled to a depth of $25 \mathrm{~m}$ in the glacier bed (personal communication from H. Röthlisberger). It is possible that bedrock reaches the glacier bed below bore hole 400. No sounding could be carried out in the reverse direction in order to check this interpretation. Relatively warm and thin subglacial permafrost in the marginal zone of the glacier tongue, where cold ice is known to be in contact with the glacier bed, cannot be detected with the electrode spacing selected and, moreover, would probably have 1 ow resistivity values (cf. Hoekstra and McNeil1, 1973).

\section{CONCLUSIONS}

Electrical resistivity soundings of glacier beds seem to provide a very useful method for studies on glacier bed topography and characteristics. Exact determination of the position of the glacier bed in bore holes is easily possible using electrodes at 
the glacier margin and in the bore holes. Resistivity soundings analogous to surface soundings, but using electrodes at the glacier bed, allow investigation of the subglacial 1ithosphere. The method could easily become a standard method for glaciological drilling projects and would then add substantially to information about glacier sliding, glacier erosion, and water flow at the glacier bed or in subglacial aquifers.

The partially cold tongue of Grubengletscher rests on unconsolidated sediments of considerable thickness (around $100 \mathrm{~m}$ or more) which contain groundwater. This example illustrates how electrical resistivity soundings of glacier beds can raise new questions as to the fundamentals of glacier movement and glacier erosion: how does a glacier slide on deformable, water-bearing sediments which have an obviously smooth surface (cf. Iken, 1981), and, how can a glacier rest on a thick accumulation of subglacial sediments if deformation of such sediments and, hence, strong glacial erosion, are important aspects of glacier sliding (cf. Boulton and Jones, 1979; Haeberli, 1981)?

\section{ACKNOWLEDGEMENTS}

Thanks are due to the colleagues who helped with the field work, to Dr H. Röthlisberger who critically read the manuscript, to $P$. Alean who edited the English, and to $W$. Nobs who prepared the figures.

\section{REFERENCES}

Bezinge, A., and others. 1973. Phēnomẽnes du $1 \mathrm{ac}$ glaciaire du Gorner, par A. Bezinge, J.P. Perreten, et F. Schafer. Union Géodésique et Géophysique Internationale. Association Internationale d'Hydrologie scientifique. Commission de Neiges et Glaces. Symposium on the Hydrology of Glaciers, Cambridge, 7-13 September 1969 , p. 65-78. (Publication No. 95 de I'Association Internationale d'Hydrologie Scientifique.)

Boulton, G.S. 1979. Processes of glacier erosion on different substrata. Joumal of Glaciology, Vol. 23, No. 89, p. 15-38.

Boulton, G.S., and Jones, A.S. 1979. Stability of temperate ice caps and ice sheets resting on beds of deformable sediment. Journal of Glaciology, Vol. 24, No. 90, p. 29-43.

Collins, D.N. 1979. Sediment concentration in melt waters as an indicator of erosion processes beneath an Alpine glacier. Journal of Glaciology, Vol. 23, No. 89 , p. 247-57.

Dohr, G. 1974. Applied geophysics: introduction to geophysical prospecting. [Translator: G.H. Kirby.] Stuttgart, Ferdinand Enke Publishers. (Geology of Petroleum, Vol. 1.)

Engelhardt, H.F., and others. 1978. Basal sliding and conditions at the glacier bed as revealed by borehole photography, by H.F. Engelhardt, W.D. Harrison, and [W.]B. Kamb. Journal of Glaciology, Vol. 20, No. 84 , p. 469-508.

Fisch, W., sr, and others. [1978.] Electrical D.C. resistivity soundings with long profiles on rock glaciers and moraines in the Alps of Switzerland, by W. Fisch Sr, W. Fisch Jr, and W. Haeberli. Zeitschrift für Gletscherkunde und Glazialgeologie, Bd. 13, Ht. 1-2, 1977, p. 239-60.
Haeberli, W. [1976.] Eistemperaturen in den Alpen. Zeitschrift für Gletscherkunde und Glazialgeologie, Bd. 11, Ht. 2, 1975, p. 203-20.

Haeberli, W. 1981. Ice motion on deformable sediments. Journal of Glaciology, Vol. 27, No. 96, p. 365-66. [Letter.]

Haeberli, W., and others. 1982. Erste Erfahrungen mit dem US Geological Survey-Monopuls Radioecholot im Firn, Eis, und Permafrost der Schweizer Alpen, von W. Haeberli, H.-P. Wächter, W. Schmid, und C. Sidler. Arbeitshefte der Versuchsanstalt für Wasserbau, Hydrologie und Glaziologie an der Eidgenössischen Technischen Hochschule (Zürich), Nr. 6. Hoekstra, P., and McNei11, D. 1973. El ectromagnetic probing of permafrost. Permafrost. Second International Conference, 13-28 July 1973, Yakutsk, U.S.S.R. North American contribution. Washington, D.C., National Academy of Sciences, p. 517-26.

Iken, A. 1981. The effect of the subglacial water pressure on the sliding velocity of a glacier in an idealized numerical model. Journal of Glaciology, Vol. 27, No. 97, p. 407-21.

Iken, A., and others. [1977.] Deep drilling with a hot water jet, by $A$. Iken, H. Röthlisberger, and K. Hutter. Zeitschrift für Gletscherkunde und Glazialgeologie, Bd. 12, Ht. 2, 1976, p. 143-56.

Iken, A., and others. 1983. The uplift of Unteraargletscher at the beginning of the melt season a consequence of water storage at the bed? By A. Iken, H. Röthlisberger, A. Flotron, and W. Haeberli Journal of Glaciology, Vol. 29, No. 101, p. 28-47.

King, L. 1982. Qualitative und quantitative Erfassung von Permafrost in Tarfala (Schwedisch-Lappland) und Jotunheimen (Norwegen) mit $\mathrm{Hilfe}$ geoelektrischer Sondierungen. Zeitschrift für Geomorphologie, Suppl.-Bd. 43, p. 139-60.

Lliboutry, L.A. 1979. Local friction laws for glaciers: a critical review and new openings. Journal of Glaciology, Vol. 23, No. 89, p. 67-95.

Robin, G. de Q. 1975. Radio-echo sounding: glaciological interpretations and applications. Journal of Glaciology, Vol. 15, No. 73, p. 49-64.

Röthlisberger, H. 1967. Electrical resistivity measurements and soundings on glaciers: introductory remarks. Joumal of Glaciology, Vol. 6, No. 47, p. 599-606.

Röthlisberger, H. 1979. Glaziologische Arbeiten im Zusammenhang mit den Seeausbrüchen am Grubengletscher, Gemeinde Saas Balen (Wallis). Mitteilungen der Versuchsanstalt für Wasserbau, Hydrologie und Glaziologie an der Eidgenössischen Technischen Hochschule (Zürich), Nr. 41, p. 233-56.

Röthl isberger, H., and Iken, A. 1981. Plucking as an effect of water-pressure variations at the glacier bed. Annals of Glaciology, Vol. 2, p. 57-62.

Süsstrunk, A. 1951. Sondage du glacier par la mēthode sismique. La Houilze Blanche, 6e An., Numéro Spécial A, p. 309-19.

Vivian, R.A., and Zumstein, J. 1973. Hydrologie sousglaciaire au glacier d'Argentière (Mont-Blanc, France). Union Géodésique et Géophysique Internationale. Association Internationale d'Hydrologie Scientifique. Commission de Neiges et Glaces. Symposium on the Hydrology of Glaciers, Cambridge, 7-13 september 1969 , p. 53-64. (Publication No. 95 de I'Association Internationale d'Hydrologie Scientifique.)

Weertman, J. 1979. The unsolved general glacier sliding problem. Journal of Glaciology, Vol. 23, No. 89, p. $97-115$.

Wold, B., and Ostrem, G. 1979. Subglacial constructions and investigations at Bondhusbreen, Norway. Journal of Glaciology, Vol. 23, No. 89, p. 363-78. 